\title{
Stress tolerant plant species spread in the road-net
}

\author{
Šerá Božena \\ Institute of Nanobiology and Structural Biology of GCRC, \\ Na Sádkách 7, České Budějovice, CZ - 37005, Czech Republic \\ e-mail: sera@usbe.cas.cz
}

\begin{abstract}
Summary. Roads are known for being corridors for not only migration of small animals, but also expansive, invasive and halophytic plants. At least sixteen wildly growing halophytes and many other salt-tolerant species were found along various types of roads in the Czech Republic. The most halophytes belonged to the families of Poaceae (23\%) and Asteraceae (20\%). Since many plants growing along roads are weeds, there is a real danger that these plants will invade nearby agricultural crops. Thus biological degradation of agricultural areas can be started.
\end{abstract}

Key words: weed, invasive, road-net, salinity, Poaceae.

\section{Introduction}

Roadsides are affected by construction repairs, road maintenance, and mowing. The vegetation of road verges and lines close to roads is affected by traffic emissions and substances added to road spreading (Bernardt-Romermann et al. 2006). The extent of harm caused to plant species depends on sensitivity of the plant species and amount of salt applications. Repeated applications of salt have led to changes in plant composition in many roadsides. Roadside verges are suitable habitats for both the occurrence and spread of weed and ruderal species (Šerá 2010; Truscott et al. 2005). Above all, roadsides are often considered as reservoirs for non-native or invasive plant species (Šerá 2010; Hansen \& Clevenger 2005). The presented research describes weed species and salt-tolerant species commonly growing along roads, describes possibilities for a spreading in the open nature and shows the most danger salt-tolerant weed species for agriculture fields.

\section{Study area and research methods}

Two investigated territories included various types of roads (motorways, roads of class II and of class III, according to http://rsd.cz) in the mesophytic region of the Czech Republic. The first study area was situated in The Českomoravská Highlands and the second in the South Bohemian region. More details about the area is in Šerá (2010).

The vascular plant species have been recorded on both sides of the roads (width $1.5-3.0 \mathrm{~m}$ ) and in the median stripe in the spring (from April to June) and autumn (from September to October). The indicator values of tolerance to saline soil conditions were taken from (Ellenberg et al. 1991). The recorded species were classified into three anthropogenic statuses: weed, ruderal and common wild plant species. Plants registered as alien species were identified according to (Pyšek et al. 2002). 


\section{Results and discussion}

251 plant vascular species (except trees and mosses) were recorded, including 35 (14\%) halophytes describes by Ellenberg et al. (1991). One plant species was from category three (Spergularia salina), two species from category two (Elytrigia repens, Puccinellia distans), and the rest of the plants (32 species) from the most soft category one. The most important halophytic species of road vegetation is Puccinellia distans, which was found along all class roads (Šerá 2008). The most halophytes belonged to the families of Poaceae (23\%), Asteraceae (20\%), Chenopodiaceae (11\%), Caryophyllaceae (6\%), Fabaceae (6\%), and Juncaceae $(6 \%)$.

The investigated anthropogenic structure differed from salt-tolerant and non-salt-tolerant species. The structure of salt-tolerant plants was: $46 \%$ ruderals, $37 \%$ weeds and $17 \%$ common wild species. The structure of non-salt-tolerant plants was in ratio: $21 \%$ ruderals, $16 \%$ weeds and $63 \%$ common wild species. Almost one quarter of the plants growing along roads was alien plant species. The invasive status of alien salt-tolerant plants differed from alien non-salt-tolerant species: invasive species dominated in the salt-tolerant category.

The salt-tolerant species grow entirely in a short distance from the road asphalt, or in the median stripe. It was found that many species, which did not have the ability to tolerate salt (according to Ellenberg et al. 1991) grow either very close to asphalt, or along the mono-species line of Puccinellia distans. For example: Agrostis gigantea, Apera spica-venti, Artemisia vulgaris, Atriplex sagittata, Cardaria draba, Centaurea jacea, Dactylis glomerata, Digitaria sanguinalis, Echinochloa crus-galli, Eragrostis minor, Lactuca serriola, Medicago lupulina, Polygonum aviculare agg. and Spergularia rubra.

Some of the species became a very significant weed (e.g. A. spica-venti, D. sanguinalis and E. crus-galli), which does harm all around the central Europe and they may spread very quickly along all road nets. Roadsides probably supported the spread of these weed species from salt verges to agricultural areas with contaminated soil.

\section{Acknowledgement}

A funding was provided by the grant No. OC10032 of the MEYS (MŠMT) and the institutional research plan No. AV0Z60870520.

\section{References}

Bernhardt-Romermann A., Kircher M., Kudernatsch T., Jacobi G. \& Fischer A., 2006, Changed vegetation composition in coniferous forests near to motorways in Southern Germany, The effect of traffic-born pollution, Environmental Pollution 143: 572-581.

Ellenberg H., Weber H. E., Düll R., Wirth V., Werner W. \& Paulißen D., 1991, Zeigerwerte von Pflanzen in Mitteleuropa, Scripta Geobotanica 18: 9-160.

Hansen M. J. \& Clevenger A. P., 2005, The influence of disturbance and habitat on the presence of non-native plant species along transport corridors, Biological Conservation 125: 249-259.

Pyšek P., Sádlo J. \& Mandák B., 2002, Catalogue of alien plants of the Czech Republic, Preslia 74: 97-186.

Šrá B., 2008, Road vegetation in Central Europe - an example from the Czech Republic, Biologia 63: 10811084.

Šerá B., 2010, Road-side herbaceous vegetation: life history and habitat preferences, Polish Journal of Ecology 58: 69-79.

Truscott A. M., Palmer S. C. F., McGowan G. M., Cape J. N. \& Smart S., 2005, Vegetation composition of roadside verges in Scotland: the effects of nitrogen deposition, disturbance and management, Environmental Pollution 136: 109-118. 